\title{
Procena uticaja na socijalni razvoj u urbanističkom i prostornom planiranju
}

\author{
Danijela Milojkić \\ Arhitektonski fakultet, Departman za urbanizam, Univerzitet u Beogradu, \\ Srbija
}

e-mail:st.milojkic@gmail.com

\begin{abstract}
SAŽETAK Evropske institucije, internacionalna udruženja i brojni teoretski radovi zastupaju stav da Procena uticaja na socijalni razvoj (Social impact assessment SIA) doprinosi stabilnom, pravednom i održivom upravljanju razvojem, sprečavajući nepotrebno trošenje novčanih i drugih resursa na neutralisanje negativnih posledica planiranih intervencija. Međutim, u dokumentima organizacija i teorijskim radovima, formulacija 'planirane intervencije' najčešće ne predstavlja intervencije urbanističkog i prostornog planiranja, već bilo koju akciju u bilo kom sektoru, koja je unapred planirana i koja ima potencijalni uticaj na kvalitet života ljudi. Nedostatak sektorske diferencijacije pri definisanju SIA u međunarodnim dokumentima i teorijskim radovima u odnosu na urbanističko i prostorno planiranje predstavlja problem za formiranje okvira u kome će se SIA sprovoditi u ovoj oblasti — javljaju se teškoće u operacionalizaciji problema, definisanju aktera, i formulisanju daljih pitanja koja se nameću pri pokušaju operacionalizacije SIA. U radu je predstavljen pokušaj da se, kroz analizu sadržaja i kritičku analizu, objedine elementi raznolikih definicija SIA i da se, nakon okvirnog definisanja SIA u prostornom i urbanističkom planiranju, identifikuju dalje smernice za istraživanja njenih elemenata, koja će stručnjacima omogućiti efikasno i efektivno upravljanje ovim mehanizmom.
\end{abstract}

Ključne riječi: elementi SIA, proizvod planiranja, razvojni procesi, donošenje odluka, posledice razvoja.

\section{Uvod}

Procena uticaja na socijalni razvoj ${ }^{1}$ (Social Impact Assessment — u daljem tekstu SIA) je nastala 70-ih godina 20-og veka, i od tada je prepoznata kao efikasan mehanizam za predviđanje negativnih uticaja intervencija prostornog i urbanističkog planiranja na socio-kulturne i humane resurse. SIA je efikasan mehanizam za sprečavanje nepotrebnog trošenja novčanih i drugih resursa na neutralisanje posledica intervencija

1 Prevod sintagme Social Impact Assessment u sintagmu Procena uticaja na socijalni razvoj je preuzet iz teksta Procena uticaja na socijalni razvoj u projektima otvaranja i širenja površinskih kopova, autora Vesne Jokić i Ksenije Petovar (Jokić i Petovar, 2010.) 
urbanističkog i prostornog planiranja, i uspostavljanje sistema stabilnog, pravednog i održivog upravljanja razvojem (Barrow, 2000.). Iako postoje brojne smernice evropskih institucija ${ }^{2}$ i međunarodnih organizacija, kao i teoretski radovi, koji opisuju proces i metodologiju SIA, relevantni autori smatraju da do danas ne postoji opšte prihvaćen okvir za sprovođenje SIA u polju urbanističkog i prostornog planiranja (Burge, 2004.a; Taylor i sur., 2006.). Iako se u dokumentima i teoretskim radovima često pojavlje formulacija 'planirana intervencija', misli se na bilo koju intervenciju, u bilo kom sektoru, za koju se zna da će biti sprovedena, bez diferencijacije u odnosu na urbanističko i prostorno planiranje. Ovo u velikoj meri otežava primenu SIA u oblasti urbanističkog i prostornog planiranja — teško je sa sigurnošću operacionalizovati probleme, aktere i druge elemente potrebne za sprovođenje SIA.

Potreba za sprovođenjem SIA paralelno sa procesom urbanističkog i prostornog planiranja ustanovljena je u odnosu na probleme u savremenoj praksi i teoriji planiranja. Savremeno planiranje, u razvijenim zemljama kao i u zemljama u razvoju, izloženo je kritikama da boluje od manjka demokratskog potencijala, da je tehnokratsko i netransparentno, (Healey, 1992., 1996.; Innes, 1996.; Anderson, 2008.; Nedović-Budić, Tsenkova and Marcuse, 2006.), kao i da su pojave tokova moći i novca u procesu planiranja neizbežne (Flyvbjerg, 1998., 2003.; Huxley, 2000.). Sve navedeno uticalo je da rezultati planskog procesa u realnosti ne postižu osnovnu svrhu planiranja - kvalitet prostora i života ljudi u prostoru, odnosno da se ovi kvaliteti u praksi često podređuju ekonomskim ciljevima (Flyvbjerg, 1998., Flyvbjerg, Bruzelius and Rothengatter, 2003.; Sager, 2005.; Fainstein 1997., 2005.). U ovakvoj situaciji, SIA predviđa i istražuje posledice planskih rešenja, koje imaju implikacije u prostoru i uticaj na socijalni razvoj, sa namerom da njima upravlja i da ih kontroliše (naročito ukoliko imaju negativni karakter). Ukoliko je stručnjacima SIA omogućeno da utiču na sadržaj plana, SIA predstavlja i kontrolu planirane akcije, odnosno njenih negativnih posledica na socijalni razvoj stanovnika planiranog područja i drugih zainteresovanih strana. Ukoliko stručnjaci SIA nemaju mogućnost da utiču na plan, SIA ima savetodavnu ili upozoravajuću ulogu o intenzitetu socijalnih posledica planske intervencije. U razvijenim zemljama se, u velikoj većini slučajeva, za urbanističke i prostorne planove sprovode Strateška procena uticaja na životnu sredinu (Strategic environmental impact assessment - SEA) i Procena uticaja na životnu sredinu (Environmental impact assessment - EIA), dok se SIA sprovodi kao deo ovih istraživanja, ali trenutno jačaju tendencije da se SIA izdvoji kao samostalni postupak.

U zemljama u razvoju je naročito izražena potreba da se uspostavi okvir za efikasno sprovođenje SIA u oblasti urbanističkog i prostornog planiranja, iz dva razloga. Prvo, zemljama u razvoju i tranziciji su potrebni efikasni mehanizmi zaštite socijalnog razvoja od negativnih uticaja razvojnih i drugih projekata u prostoru. Tranzicija retko ima respekta prema socijalnim ciljevima u odnosu na ekonomske, a socijalna regresija je uobičajen pratilac određenih perioda tranzicije (Lakićević,

2 http://ec.europa.eu/social/main.jsp?catId=760\&langId=en; http://ec.europa.eu/governance/ impact/index en.htm; http://www.peer-review-social-inclusion.eu/ 
2001.). U ovakvim uslovima su sistemi planiranja i planeri kritikovani kao preterano oportunistički i previše fleksibilni u odnosu na potrebe parcijalnih interesa (najpre kapitala), uz nehajan odnos prema socijalnim ishodima (Stanilov, 2007.; Tsenkova and Nedović-Budić, 2006.). Drugo, tokom poslednje decenije, veliki broj međunarodnih finansijskih organizacija usvaja SIA kao efikasan alat za predviđanje negativnih posledica planiranih intervencija. World Bank (2003.a, 2010.), European Investment Bank (2010.) i European Bank for Reconstruction and Development (2008., 2009.a, 2009.b) u pojedinim slučajevima zahtevaju od zemalja u razvoju da prilože SIA uz projektnu dokumentaciju za odobravanje kreditnih aranžmana (za finansiranje/kreditiranje infrastrukturnih i drugih razvojnih projekata u zemljama u razvoju). Pri aplikaciji za kredite, zemlje u razvoju imaju problem sa sprovođenjem SIA, jer nemaju odgovarajuću zakonsku podlogu, i celokupni proces oslanjaju na zakone iz drugih oblasti koji pokrivaju određene segmente SIA. Ipak, nacionalne institucije zemalja u razvoju ne pokazuju veliki interes za uvođenje SIA, za razliku od SEA i EIA (Momtaz, 2005.; Baines and Taylor, 2002.; Henry, 1990.). Nezavisno od nacionalne regulative, privatni investitori ponekad pronalaze interes za sprovođenje SIA kao deo PR strategije pri objavljivanju namera o implementaciji projekata, kako bi omogućili sebi „bezbrižan dolazak na gradilište“ (Akpofure and Ojile, 2002.:217).

Uslov za efikasno funkcionisanje SIA u oblasti prostornog i urbanističkog planiranja (u sastavu SEA/EIA ili nezavisno) je postavljanje okvira za njeno sprovođenje i operacionalizaciju njenih elemenata u odnosu na urbanističko i prostorno planiranje. Jedan od problema sa postavljanjem ovog okvira je nedostatak konzistentne i dovoljno operativne definicije, kroz koju bi dalje mogli da se definišu ciljevi, indikatori i drugi elementi SIA, i na koju bi se oslonile dalje analize i istraživanja o SIA u urbanističkom i prostornom planiranju. Postojeće definicije SIA su raznovrsne i neusaglašene, uopštene i bez diferencijacije u odnosu na oblasti u kojima se SIA sprovodi. U ovom prilogu je napravljen pokušaj da se, analizom sadržaja i kritičkom analizom, iz velikog obima postojećih definicija izdvoji definicija SIA u oblasti prostornog i urbanističkog planiranja, na osnovu koje će moći da se pristupi daljim analizama SIA. Pregled definicija omogućava da se u drugom delu rada izdvoje teme za dalje istraživanje (opšti/osnovni elementi SIA, veza procesa SIA i procesa prostornog i urbanističkog planiranja) i probleme koji se očekuju u sklopu ovih istraživanja.

\section{Uporedni prikaz i analiza definicija SIA prema zajedničkim odrednicama}

Osnovni cilj ovog poglavlja je formiranje definicije SIA u procesu prostornog i urbanističkog planiranja, kroz analizu definicija SIA u radu tri organizacije i tri autora $^{3}$. Primećeno je da su ovi radovi imali veliki odjek u naučnoj javnosti i da drugi

3 Pojedini izabrani autori su bili učesnici u izradi izabranih dokumenata, u koje su ugradili svoje stavove o SIA (Rabel Burdge i ICGPSIA, Franc Vanclay i IAIA). Ovo je razlog što se pojedini stavovi o SIA doslovno ponavljaju u pregledu dokumenata i autorskih radova. Ipak, autori su u svojim individualnim radovima napravili bitne iskorake u odnosu na dokumenta na kojima su radili unutar organizacija, i s toga je bitno da njihovi doprinosi definisanju SIA budu detaljno analizirani. 
relevantni autori i organizacije citiraju izabranu grupu autora pri definisanju SIA u svojim radovima (Barrow, 2000.; Taylor, Bryan and Goodrich, 2004.; Becker, 2001.; Taylor, Goodrich, Fitzgerald and McClintock, 2006.; Petovar i Jokić, 2010.). U pitanju su: Internacionalno udruženje za procenu uticaja - International Association of Impact Assessment, IAIA - International Principles for social impact assessment; Institut za studije o životnoj sredini - Interorganizational Committee on Guidelines and Principles for Social Impact Assessment ICGPSIA; Svetska banka World bank; William R. Freudenburg; Rabel J. Burdge; i Franc Vanclay.

U definicijama SIA se prepoznaju zajednička pitanja koja autori postavljaju, tj. elementi i odrednice koji ukazuju na obim/sadržaj ovog pojma, iz kojih će u daljem radu biti izdvojeni segmenti adekvatni za formiranje definicije SIA u urbanističkom i prostornom planiranju:

- $\quad$ šta je SIA, odnosno kakav je proces u pitanju;

- $\quad$ koja vrsta planirane akcije izaziva uticaje;

- $\quad$ ko je pogođen uticajima (objekat uticaja);

- $\quad$ koja je svrha (cilj) SIA;

- koje konkretne intervencije izazivaju uticaje (konkretne planske intervencije za koje je potrebna izrada SIA);

- $\quad$ koji uticaji mogu nastati (kao posledica planirane intervencije);

- kakav je odnos prema participaciji interesnih grupa i javnosti u SIA.

Kako bi izbegli pojmovne nesporazume, pre analize postojećih definicija, još jednom napominjemo da autori (na čije definicije SIA moramo da oslonimo istraživanje u nedostatku definicija specijalizovanih u oblasti urbanističkog i prostornog planiranja) najčešće koriste termin 'planirane intervencije/akcije' u uopštenom, sektorski neodređenom smislu. U tekstu će posebno biti naglašeno kada su ovi termini vezani za urbanistilko i prostorno planiranje.

\section{Šta je SIA}

Freudenburg (1986.) zauzima stav da je SIA prospektivni planerski alat. U slučaju urbanističkog i prostornog planiranja ovakvo shvatanje moramo uzeti sa rezervom, s obzirom da SIA nije samo alat, već samostalni postupak koji se odvija paralelno sa procesom planiranja, sa kojim se dopunjuje (planeri i stručnjaci SIA ${ }^{4}$ u toku pro-

${ }^{4}$ U članku se pod stručnjacima i stručnim timovima podrazumevaju lica koja su specijalno obučena/obrazovana za izradu SIA. Ne isključuje se mogućnost učešća lica koja nisu specijalno obučena, a koja mogu da doprinesu svojim znanjima i iskustvima. Barrow (2000.) i Burdge (2004.a) ističu da je jedan od problema SIA što proces najčešće vrše lica koja nemaju odgovarajuću obuku, obrazovanje ili dovoljno iskustva u ovoj oblasti. Pojavljuje se rizik ukoliko neiskusna/nestručna lica obavljaju SIA, jer mogu da steknu lažni osećaj sigurnosti. SIA nije savršena — čak i ako precizno predvidi direktne uticaje, može da previdi druge, zajedno sa nekim (ili svim) indirektnim uticajima i kumulativnim efektima. Neophodno je napomenuti da uspešnost i preciznost SIA direktno zavisi i od brojnih drugih faktora, kao što su broj i vrsta indikatora koji se uzimaju u obzir u procesu procene, upoznatost sa detaljima/specifičnostima plana i postojećim stanjem, itd. 
cesa urbanističkog i prostornog planiranja i postupka procene uticaja razmenjuju informacije: planeri pružaju informacije o karakteristikama i specifičnostima plana i planskog rešenja, a stručnjaci SIA o socijalnim posledicama istog). Ukoliko je neophodno da SIA imenujemo jednom rečju, umesto reči 'alat' možemo upotrebiti reč 'mehanizam', koja više pristaje jednom relativno samostalnom i složenom postupku. Freudenburg navodi i da je SIA procenjivanje, merenje i rezimiranje uticaja (1986.), Burdge (2009.) da je SIA sistematska analiza uticaja, a IAIA da je procena uticaja paradigma koja se sastoji iz tehnika, znanja i vrednosti (2003.) — ove konstatacije su isuviše opšte da bi saznali koje su to tehnike, znanja i vrednosti.

ICGPSIA smatra da je SIA alatka koja pomaže pri donošenju odluka da li će neka akcija biti sprovedena ili ne, ali se za potrebe definisanja SIA u urbanističkom i prostornom planiranju ne možemo isključivo osloniti ni na ove konstatacije jer trenutna praksa pokazuje težnju da se SIA sprovodi i nakon implementacije određenog plana ili akcije. U pitanju je takozvana ex post SIA, gde se procenjuju već nastali uticaji na socijalni razvoj i učinak procesa SIA (evaluacija), nakon implementacije određene intervencije. U pitanju su svojevrsne studije slučajeva, baze podataka o prethodnim procenama, koje omogućavaju stručnjacima SIA da, pri susretu sa sličnim intervencijama, imaju bolji uvid u moguće ishode (Becker, 2004.). Iako ne obrađujemo ovaj postupak, bitno je naglasiti da stručnjaci prepoznaju ex post SIA kao neophodan element za sprovođenje SIA u urbanističkom i prostornom planiranju (Čaldarović i Šarinić, 2010.) smatraju da je teško izraziti sociološke posledice promene prostora zbog nedostatka prethodnih podataka o ugroženosti različitih dimenzija života usled problema u planiranju prostora. ${ }^{5}$

IAIA (2003.) i Vanclay (2006.) konkretno navode da je SIA proces analize, nadzora (monitoringa) i upravljanja posledicama razvoja koje menjaju kvalitet života i osećaj blagostanja. Ipak, kako bi ova konstatacija bila prilagođena oblasti urbanističkog i prostornog planiranja, mora da sadrži element prostora - konkretno prostorni razvoj ${ }^{6}$. Konstatacija Svetske banke (2010.) da je SIA multimetodska tehnika za ispitivanje uticaja se poklapa sa tvrdnjama koje iznose IAIA i Vanclay. Ipak, Svetska banka daje drugi doprinos definiciji svojom konstatacijom o iteracijama, odnosno da se proces SIA sprovodi postupno, sa stalnim proverama i ponovnim sprovođenjem određenih koraka, jer podrazumeva i monitoring — paralelno sa urbanističkim i prostornim planiranjem ovo podrazumeva proveru efekata planskih rešenja i intervencija na kvalitet života, blagostanje i interese aktera pod uticajima.

5 U daljem radu se nećemo posebno baviti pitanjem ex post SIA, s obzirom da je ovaj postupak daleko sličniji metodi studije slučaja, nego postupku SIA kada se on sprovodi u trenutku donošenja odluke o budućoj inicijativi ili za vreme formiranja nekog plana. Za dalje informacije pogledati Becker, 2004.

6 Otvoreno je pitanje da li u slučaju urbanističkog i prostornog planiranja uvek možemo tvrditi da je u pitanju razvoj, ili samo promena, zaštita postojećeg, kao neutralan pojam, iako ćemo u daljem tekstu primetiti da pojedini autori izjednačavaju planirane intervencije sa razvojnim procesima. 
Na pitanje Šta je SIA u oblasti urbanističkog i prostornog planiranja, iz postojećih definicija izdvajamo da je u pitanju iterativni proces predviđanja, analize, upravljanja i monitoringa posledicama planiranih intervencija prostornog i urbanističkog planiranja, tj. uticaja na socijalni razvoj, koji pomaže pri donošenju odluke o sprovođenju planirane akcije.

\section{Vrste aktivnosti/akcija koje izazivaju uticaje}

Raspon aktivnosti/akcija koje bi, prema shvatanju izabranih autora, trebalo da budu predmet SIA kreće se od politika, planova, projekata, do neplaniranih društvenih i prirodnih pojava (prirodne katastrofe, demografske promene, ekonomsko slabljenje zajednice, epidemije... Freudenburg, 1986.; ICGPSIA, 2003.; Burdge, 2003.; IAIA, 2003.). S obzirom na karakter prostornog i urbanističkog planiranja — namerna akcija, otvoreno je pitanje da li neplanirane društvene, a naročito prirodne pojave ${ }^{7}$, mogu biti predmet SIA u oblasti prostornog i urbanističkog planiranja. Freudenburg (1986.) i Svetska banka (2010.) smatraju da SIA treba da proširi svoje polje delovanja na uticaje predrasuda i stejkholdera u procesu odlučivanja. S obzirom da je ovo pitanje trenutno u centru pažnje teorijskih i praktičnih rasprava o prostornom i urbanističkom planiranju, čini se da bi angažovanje SIA oko iste teme predstavljalo duplo trošenje novčanih, vremenskih i intelektualnih resursa.

Sa druge strane, Burdge (2009.), Vanclay (2006.) i ICGPSIA (2003.) navode da uticaji nastaju sprovođenjem različitih razvojnih procesa: planiranih javnih ili privatnih intervencija - projekata, politika, planova i programa (Vanclay ove intervencije naziva razvojnim procesima). Ovo je izuzetno kompatibilno sa prostornim i urbanističkim planiranjem, s obzirom da su projekti i programi sastavni deo planova (naročito strateških), a da politike prostornog uređenja postaju sve aktuelnije u oblasti planiranja (prostor je postao nova dimenzija politike EU, kroz dokument European spatial development perspectives — ESDP, 1999.). Svakako, s obzirom da SIA definišemo u oblasti prostornog i urbanističkog planiranja, neophodno je da dodamo da politike, planovi, programi i projekti moraju imati posredne ili neposredne implikacije u prostoru. Propust u ovakvoj formulaciji može se uočiti u stavu da uticaje izaziva sprovođenje planiranih intervencija, s obzirom da se u literaturi o SIA često pojavljuju slučajevi kada uticaji, sa jednako velikim posledicama, nastaju i samom objavom da će određeni urbanistički, odnosno prostornni plan/projekat... biti izrađen ili sproveden, ili u toku izrade istog. Primer za ovakvu pojavu predstavljaju objave o donošenju urbanističkih i prostornih planova koji podrazumevaju

\footnotetext{
7 Ukoliko se SIA sprovodi za projekat revitalizacije i rekonstrukcije područja pogođenih prirodnom katastrofom, uticaji prirodnih pojava (zemljotresa, poplava, klizišta,...) mogu biti predmet SIA, u smislu istraživanja postojećeg stanja, koje je sastavni deo SIA. Treba imati na umu da ni u ovom slučaju prirodna pojava ne pripada vrstama aktivnosti za koju se vrši SIA u oblasti prostornog i urbanističkog planiranja, koje pokušavamo da definišemo, već se istraživanje uticaja prirodne pojave vrši za potrebe procene uticaja projekta revitalizacije pogođenog područja.
} 
prinudno (neželjeno) raseljavanje stanovništva; ${ }^{8}$ ukoliko je porodicama predočeno da će biti raseljene, kvalitet njihovog života se menja usled pojave predmigratornog stresa: suočavanje sa činjenicom da će promeniti mesto života, radno mesto, odvojiti se od prijatelja, itd. (Burdge and Johnson, 2004.)

Možemo usvojiti da uticaje izaziva: sprovođenje (ili vest o nameri i izrada) planiranih privatnih ili javnih intervencija — politika, planova, programa i projekata, koji imaju direktne ili posredne implikacije u prostoru. SIA može posmatrati i analizirati uticaje stejkholdera na donošenje odluka, kao i uticaje predrasuda u procesu odlučivanja, ukoliko isti imaju uticaja na socijalni razvoj kroz predloženu intervenciju.

\section{Vrste uticaja}

U pogledu vrsta uticaja, definicije koje daju Freudenburg (1986.) i Svetska banka (2010.) ne mogu dovoljno da doprinesu formiranju definicije SIA u oblasti urbanističkog i prostornog planiranja. Freudenburg tvrdi da su u pitanju uticaji za koje su društvene nauke utvrdile da imaju velike implikacije na kvalitet života društvenih grupa. Autor ne pruža podatke o literaturi koju ima na umu kada pominje uticaje definisane u društvenim naukama, pa konstatacija više deluje kao uputstvo za definisanje uticaja. Svetska banka se uglavnom isključivo koncentriše na materijalne aspekte života ljudi, na koje određena intervencija utiče (zapošljavanje, pristupačnost dobara i servisa, imovina, porezi...). Iz ovih razloga, pažnju posvećujemo autorima koji su dali preciznija viđenja vrsta uticaja koje SIA posmatra.

U dokumentu IAIA (2003.) je predloženo da bi trebalo da posmatramo uticaje na društvo kao promene načina života, kulture, političkih sistema... Ipak, ove promene su krajnja posledica pojedinih sektorskih intervencija, tj. uticaja koji date intervencije imaju na socijalni razvoj, i bilo bi veoma zbunjujuće da se ovi elementi izjednače. Burdge (2009.) i ICGPSIA (2003.) smatraju da su uticaji na socijalni razvoj posledice intervencija koje utiču na život ljudi, njihov rad, vreme dokolice, način na koji grade međusobne odnose, organizuju se da zadovolje svoje potrebe, i generalno kako funkcionišu kao članovi društva.

Međutim, najdalje ide Vanclay (2002.), koji smatra da je veoma važno napraviti razliku između procesa društvenih promena, koje izazivaju uticaje, i samih uticaja na socijalni razvoj. Mnoge društvene promene nisu same po sebi uticaji. Ukoliko pod uticajem na socijalni razvoj usvojimo da to mora biti pojava koju ljudi osećaju psihički ili fizički, ispostavlja se da mnogi uticaji, koji su mereni u različitim procesima SIA - npr. porast populacije, nisu zaista uticaji, već procesi promena koji mogu uzrokovati uticaje. Uticaj se zatim izražava kroz smanjen osećaj zajedništva,

8 Slučaj sela Doel u Belgiji je jedan od radikalnih primera, gde se čitavo stanovništvo iselilo iz mesta pre početka izrade konkretnog plana, usled objave vlasti da će se obližnja luka proširiti i da će doći do prinudnog iseljenja. Za više detalja pogledati Gibbs and Haughton, 2008.; Marx, 2002. 
socijalne kohezije i pripadnosti zajednici. Vanclay dalje nabraja da su društvene promene demografski procesi, ekonomski procesi, geografski procesi, institucionalni i zakonodavni procesi, procesi emancipacije i osnaživanja, sociokulturni procesi, i drugo. Prema stavu koji Vanclay zastupa, uticaji na socijalni razvoj se dele prema objektu uticaja: uticaji na zdravlje i društvenu dobrobit (npr. ishrana — sigurnost/kvalitet hrane kojom se domaćinstvo snabdeva), uticaji na kvalitet životnog okruženja (buka, zagađenje vazduha, promena okruženja,...), uticaji na ekonomsku/ materijalnu dobrobit (Životni standard, vrednost nekretnina...), uticaji na kulturu (promena kulturnih vrednosti - moralni principi, verovanja...), uticaji na porodicu/ zajednicu (stopa razvoda, obaveze prema starijim članovima porodice,...), uticaji na institucije, politiku, zakonodavstvo i jednakost (participacija, povrede ljudskih prava...), uticaji na rodnu ravnopravnost (pravo na donošenje odluka o sopstvenom telu, odgajanje dece...).

Za definisanje vrsta uticaja, u oblasti urbanističkog i prostornog planiranja, usvajamo Venklejevu klasifikaciju uticaja, ali izostavljamo uticaje na rodnu ravnopravnost i uticaje na porodicu i zajednicu, jer ne sadrže ni jednu komponentu koju mogu da izazovu intervencije urbanističkog i prostornog planiranja (i u ostalim skupovima postoje uticaji koje intervencije planiranja ne mogu da izazovu, ali su prisutni u manjem broju - Vanclay, 2002.).

\section{Ko je pogođen uticajima}

Iako je za skoro sve izvore zajedničko da je društvo objekt uticaja planiranih intervencija (Freudenburg, 1986.; ICGPSIA, 2003.; IAIA, 2003.; Vanclay, 2006.; World bank, 2010.), ovakva formulacija nije operativna za definisanje SIA u oblasti prostornog i urbanističkog planiranja. Svetska banka identifikuje i institucije kao potencijalno ugrožene (2010.), Burdge (2003.) i Vanclay (2006.) dodaju da su u pitanju individue, grupe i zajednice, dok ICGPSIA (2003.) obuhvata sve ove grupe i sugeriše da objekt uticaja moraju biti svi koji su pogođeni određenom akcijom: lokalne/regionalne zajednice, stejkholderi i druge zainteresovane strane. Problem sa definicijom ICGPSIA je izostanak pojedinaca kao potencijalno ugroženih —uticaji koji pogađaju pojedince su jednako bitni kao i oni koji pogađaju veliki broj ljudi. Takođe, značenje zajednice ne bi trebalo shvatati samo u odnosu na njenu prostornu komponentu, s obzirom da zajednice podrazumevaju čitave mreže različitih odnosa, koje se međusobno preklapaju (lokalne zajednice sadrže mnoštvo verskih zajednica, virtuelnih zajednica, kulturnih zajednica... koje prevazilaze teritoriju lokalne zajednice). ${ }^{9}$ Formulacija 'druge zainteresovane strane', kojom je u dokumentu ICGPSIA završen

9 Barrow (2000.) napominje postoje različiti tipovi zajednica — regionalne, nacionalne, ruralne, urbane, etničke, lokalne; tu su i planski građene/formirane i neplanski formirane lokalne zajednice, one sa stabilnim razvojem, sa brzim porastom broja članova, zajednice sa problemima, zajednice povezane interesima, a ne prostorom, zajednice čiji kvalitet opada. Jedna zajednica može imati više ovih karakteristika, a jedna osoba može pripadati jednoj ili više zajednica. 
spisak potencijalno ugroženih, je neoperativan za formulaciju definicije. Na kraju, u oblasti urbanističkog i prostornog planiranja možemo usvojiti da objekt uticaja predstavljaju svi akteri pogođeni planiranom akcijom — institucije, zajednice, individue i stejkholderi (zainteresovane strane).

\section{Svrha/cilj SIA}

Osnovna svrha SIA je da predvidi potencijalne negativne (i pozitivne ${ }^{10}$ ) uticaje odrecene odluke i njihov intenzitet, kako bi se isti izbegli i kako bi se proverila održivost sprovođenja ispitivane intervencije (Freudenburg, 1986.; ICGPSIA, 2003.). $\mathrm{Na}$ ovaj način, SIA bi trebalo da osigura maksimizaciju dobrobiti i minimizaciju štete konkretne intervencije (Vanclay, 2006.; ICGPSIA, 2003.; IAIA, 2003.). SIA obezbeđuje informacije donosiocima odluka (i obrađivačima planova, u procesu urbanističkog i prostornog planiranja) o socijalnim i kulturnim faktorima važnim za donošenje odluke (ICGPSIA, 2003.) i o saznanjima kako će se individue, grupe i zajednice prilagoditi promenama (Vanclay, 2006.). Sa druge strane, SIA pomaže potencijalno pogođenim stranama da bolje shvate moguće posledice i da se za iste pripreme. (Burdge, 2003.) Komunicirajući i sa donosiocima odluka i sa građanima, SIA omogućava inkorporisanje lokalnog znanja i vrednosti u proces donošenja odluka (ICGPSIA, 2003.), a ujedno pomaže licima koja donose odluke da identifikuju socijalno najpovoljniju akciju u lokalnom, regionalnom ili nacionalnom interesu (Burdge, 2003.; Vanclay, 2006.).

Iako se u dokumentu ICGPSIA (2003.), kao i kod Burdge-a (2003.) i Vanclay-a (2006.) pominje da SIA može da ponudi alternative za predloženi projekat ili da zaustavi sprovođenje intervencije koja je izuzetno nepovoljna po socijalni razvoj, ovakve stavove možemo uzeti sa rezervom. Kada je u pitanju urbanističko i prostorno planiranje, praksa u nekoliko slučajeva pokazuje da je mogućnost stručnjaka SIA da utiču na zaustavljanje implementacije plana i na izmenu njegove forme, vrlo mala. U slučaju Sterling Medousa (US) stručnjaci SIA su predvideli brojne negativne uticaje koje će izvedeni projekat imati na stanovništvo, ali bez obzira na rezultate SIA, u planu nije došlo do značajnih izmena (pogledati Burdge and WWs, 2004.). U slučaju sela Doel (Belgija), građani su se pravnim putem izborili da se razultati SIA uzmu u obzir prilikom izrade projekta za njihovo mesto, ali su vlasti pronašle mogućnost da plan sprovedu u delo (Gibbs and Haughton, 2008.; Marx, 2002.). Preostaje da je svrha SIA da ispita da li će postojati merljiva razlika u kvalitetu života zajednice usled promene izazvane planom (Burdge, 2003.), bez obzira na mogućnost SIA da neku odluku preinači/ zaustavi. Cilj SIA je kvalitetnije okruženje po pitanju socio-kulturne održivosti i pravičnosti, kako je objašnjeno u dokumentu

10 U postupku SIA, stručnjaci mogu da se usmere i na pozitivne efekte koje će razvojni procesi imati. Konstatacije u ovakvoj analizi doprinose da se pozitivni efekti istaknu, i ukoliko je moguće uvećaju, maksimiziraju u toku procesa planiranja i implementacije plana. Treba imati u vidu i da ovakvo proširenje SIA podrazumeva veću potrošnju vremenskih i novčanih resursa, o čemu će kasnije biti reči. 
IAIA (2003.), ali ne treba stručnjacima SIA pripisivati i odgovornost za postizanje ovog cilja, s obzirom da to zavisi od donosilaca odluka.

U dokumentu IAIA (2003.), a kako i Vanclay tvrdi (2006.), jedna od svrha SIA u razvijenim zemljama je očuvanje prava privatnog vlasništva ili ublažavanja negativnih efekata ukoliko su prava već povređena. Ipak, pitanje je da li je potrebno izdvajati pojedinačne segmente života pod protektoratom SIA, ukoliko je prethodno utvrđeno da je osnovna svrha SIA da spreči negativne posledice razvojnih procesa na ukupan kvalitet života. Slično se događa sa interpretacijom svrhe SIA koju daje Svetska banka. U ovom dokumentu centralna tema nije opšti kvalitet života, već potencijalni dobitnici i gubitnici predviđene intervencije (World bank, 2010.). Svetska banka više posmatra materijalni aspekt celokupnog procesa, što se može prihvatiti kao praktičan i operativan pogled na celokupni problem - merenjem ekonomske dobiti i gubitaka tokom ciklusa jedne intervencije bi se najlakše operacionalizovali intenzitet i karakter uticaja određenog projekta. Iako Svetska banka posmatra samo sprovođenje reformi javnih politika, ovakav pristup može biti usvojen i u sprovođenju SIA u oblasti prostornog i urbanističkog planiranja. Svakako, ostaje otvoreno pitanje da li se sve može izmeriti novcem i da li će izmerena vrednost u novcu zaista da odgovara veličini štete ${ }^{11}$. Trebalo bi uzeti u obzir da Svetska banka koristi novac kao indikator za opstanak planirane reforme: ograničenja za sprovođenje reforme, kako će ljudi i institucije reagovati na reformu, da li su predviđanja o ovim reakcijama ispravna... (World bank, 2003.a) — novac u ovim slučajevima verovatno može da da relativno precizne rezultate.

S obzirom da stručnjaci SIA retko mogu da utiču na izgled i ishod planirane intervencije u urbanističkom i prostornom planiranju, nepotrebno je pripisivati ovu svrhu SIA i opteretiti ovaj proces većom odgovornošću od one koja joj je realno data u praksi. Otvoreno je pitanje da li je moguće obavezati planere/donosioce odluka da preporuke stručnjaka SIA unesu u alternativna planska rešenja. Ne izostavlja se mogućnost da SIA utiče na ishod plana, ali napominjemo da ovo nije obavezna svrha SIA. Cilj SIA u urbanističkom i prostornom planiranju je da predvidi/proceni uticaje planske intervencije na socijalni razvoj, kako bi se izbegli/minimizirali negativni uticaji, a maksimizirali pozitivni; SIA odgovara na pitanje da li će postojati merljiva razlika u kvalitetu života zajednice nakon realizacije plana i doprinosi kvalitetu donešene odluke o konkretnoj intervenciji.

\section{Konkretne intervencije koje izazivaju uticaje}

Kada su u pitanju intervencije koje izazivaju uticaje, autori se, uglavnom, ne odlučuju za konkretne projekte (iako ima pokušaja), već navode da SIA može da se primeni

\footnotetext{
11 Pitanje je da li novcem može da se izmeri stres kojem je izloženo prinudno raseljeno stanovništvo ili da se izmere uticaji koje izaziva rušenje škole koja je predstavljala ponos zajednice dugi niz godina.
} 
na širokom spektru intervencija (Freudenburg, 1986.; ICGPSIA, 2003.; Burdge, 2003.; Vanclay, 2006.; IAIA, 2003.), unutar i izvan regulisanog okvira (IAIA, 2003.), što se čini i pogodnom formulacijom za definiciju SIA u urbanističkom i prostornom planiranju. Pojedini autori navode i neplanirane akcije i pojave kao potencijalne izvore uticaja (ICGPSIA, 2003.; Burdge, 2003.), ali s obzirom da pokušavamo da definišemo SIA u oblasti prostornog i urbanističkog planiranja, možemo izostaviti ove konstatacije. Iako Svetska banka (2003.) posmatra samo reforme politika, važna je konstatacija da SIA nije prigodan mehanizam kada su u pitanju velike reforme, gde nije moguće identifkovati pravce uticaja i grupe stejkholdera.

\section{Odnos prema participaciji interesnih grupa $i$ javnosti u SIA}

Osim dokumenta IAIA, ostali autori se zalažu za određene vidove participacije javnosti i zainteresovanih strana u procesu SIA. Ovaj proces je u različitim izvorima različito predstavljen (zamišljen). Freudenburg (1986.) i Burdge (2003.) razmatraju učešće zajednice u donošenju odluka, dok ICGPSIA (2003.) i Svetska banka (2003., 2010.) participaciju navode samo kao dodatnu i pogodnu mogućnost pribavljanja informacija i lokalnih znanja, bez uključivanja javnosti u proces donošenja odluke. Otvoreno je pitanje kako bi izgledalo uključivanje građana u proces donošenja odluka, ukoliko se SIA sprovodi paralelno sa nekim od neparticipativnih procesa urbanističkog i prostornog planiranja. Ovo pitanje je naročito značajno u zemljama u razvoju gde komunikativno-kolaborativni modeli urbanističkog i prostornog planiranja nisu predviđeni regulativom i u potpunosti prihvaćeni od strane struke. Stručnjaci SIA svakako posredno uključuju građane u proces donošenja odluka tako što donosiocima odluka i planerima prenose stavove/strahove građana o ispitivanoj intervenciji.

\section{Definicija SIA u oblasti prostornog i urbanističkog planiranja}

U odnosu na prikazani pregled, možemo sastaviti preliminarnu definiciju SIA.

SIA je iterativni proces predviđanja, analize, monitoringa i upravljanja uticajima koje ce izazvati sprovođenje planiranih intervencija prostornog i urbanističkog planiranja i svim promenama koje usled njih nastaju, a koje ce osetiti institucije, zajednice, individue i stejkbolderi - svi akteri pogođeni planiranom akcijom. Pod razvojnim procesima se podrazumevaju politike, planovi, programi i projekti, direktno usmereni na prostor ili sa posrednim implikacijama.

Cilj SIA je da predvidi uticaje planirane intervencije na socijalni razvoj i njibove uzroke, kako bi se izbegli ili minimizirali negativni uticaji (uz mogućnost sprečavanja akcije), a maksimizirali pozitivni. SIA mora da odgovori na pitanje da li ce postojati merljiva razlika u kvalitetu života zajednice nakon sprovođenja akcije. Ove odgovore stručnjaci SIA nalaze i u procesu participacije, gde crpe informacije iz lokaInog znanja $i$, na taj način, posredno uključuju zainteresovane i pogođene strane 
u proces donošenja odluka. Rezultati SIA bi u planskom procesu trebalo da usmere planere, stejkholdere i donosioce odluka ka kvalitetnijoj odluci.

Uticaji na društvo mogu se klasifikovati na: uticaje na zdravlje i društvenu dobrobit; uticaje na kvalitet životnog okruženja ${ }^{12}$; uticaje na ekonomsku i materijalnu dobrobit; uticaje na kulturu. U odnosu na raznovrsnost uticaja, SIA se može primeniti za širok spektar planiranih intervencija, unutar i izvan regulisanog okvira.

S obzirom da je SIA nov postupak i u razvijenim zemljama, očekuje se još puno istraživanja, na osnovu kojih će se data definicija menjati. U svom trenutnom obliku, ona ima svrhu da olakša započinjanje pomenutih daljih istraživanja.

\section{Predlozi tema za dalja istraživanja SIA u oblasti urbanističkog i prostornog planiranja}

\section{Vrste projekata za koje se sprovodi SIA}

Većina konstatacija na temu vrsta projekata za koje se sprovodi SIA je opšteg karaktera - Taylor, Bryan and Goodrich (2004.) smatraju da svaka izmena u prostoru ima društvene implikacije; Becker (2001.) navodi da su u pitanju problemi toliko komplikovani da zahtevaju dodatnu akciju; u dokumentu ICGPSIA (2003.) je napravljena specifikacija/spisak projekata za koje je potrebno sprovoditi SIA, uz napomenu da je u pitanju samo ilustracija. Ovo je uslovilo da se definisanje vrsta projekata, za koje se sprovodi SIA u urbanističkom i prostornom planiranju, kreće između precizno definisanog spiska projekata i nejasno definisane odrednice da se projekti, za koje se sprovodi SIA, kreću između pozicioniranja nuklearnih elektrana do pozicioniranja parka u gradskoj matrici. Preostaju brojna pitanja: za koje projekte je potrebno sprovoditi SIA; da li postoji spisak planskih intervencija iz kog bi mogli da izdvojimo one za koje je potrebno sprovoditi SIA; da li je bolje razmatrati ovo pitanje od slučaja do slučaja; kako bi izgledao set kriterijuma za ocenu potrebe izrade SIA u urbanističkom i prostornom planiranju; itd.

\section{Saradnja sa akterima}

U odnosu na raspoložive novčane, vremenske i ljudske resurse, potrebne za sprovođenje SIA u urbanističkom i prostornom planiranju, stručna lica SIA bi trebalo da odrede sa kojim akterima će sarađivati — da li će to biti svi pogođeni akteri, ili samo oni koji trpe negativne uticaje, samo stejkholderi, najugroženiji, itd. Odluka

12 Kako ne bi došlo do nesporazuma između polja delovanja SIA i SEA/EIA, pod životnim okruženjem se ne smatra prirodna sredina, već ukupno čovekovo okruženje, prirodno i građeno, sa svojim funkcionalnim, organizacionim, estetskim i dr. kvalitetima koji su pod dejstvom prakse urbanističkog i prostornog planiranja. 
direktno zavisi od obima SIA (npr. ukoliko stručnjaci SIA odluče da predvide i pozitivne i negativne uticaje SIA, skup aktera se proširuje i na aktere koji su pod pozitivnim uticajima). U literaturi i praksi se preklapaju dva pristupa, koje zastupa i Svetska banka - uključivanje svih potencijalno pogođenih aktera ili uključivanje samo najugroženijih grupa (World bank, 2003.a, 2010.). Bez obzira na krajnji ishod, bitno je da stručnjak na početku razmotri uključivanje svih aktera (ovakav postupak bi dao najoptimalnije rezultate), ali je važno da sagleda posledice takvog postupka - ponekad potencijalno pogođeni akteri mogu biti brojni, a postupak njihovog uključivanja zahtevan, skup i dug. Svetska banka (2003.), kao što je navedeno ranije, zastupa stav da u ovim slučajevima SIA nije adekvatan postupak. Ovakva situacija može da se zloupotrebi za izostavljanje pojedinih grupa aktera ${ }^{13}$, i potrebno je pronaći zaštitni mehanizam za ovakve slučajeve. U slučajevima kada imamo veliki broj aktera, postavlja se pitanje da li je komuniciranje sa tipičnim predstavnicima jedini izbor i adekvatna zamena opštoj participaciji; kako izgleda proces upoznavanja sa akterima i njihovo uključivanje u proces SIA? Koje informacije je potrebno dobiti od potencijalno pogođenih aktera? Kako izgleda program za uključivanje javnosti u monitoring tokom procesa implementacije?

Za definisanje aktera, od velike pomoći je klasifikacija teoretičara participativnog planiranja. Oni razlikuju tri grupe aktera (zajednica): aktere koji se nalaze na datom području i dele brigu, pogođeni su onim što se tu dešava; aktere koji su van područja plana, ali u dometu uticaja, koji nemaju druge interese vezane za područje pod planom; i aktere koji direktno ili indirektno imaju interese u datom prostoru ili brinu o tome šta ljudi iz prve grupe rade u tom mestu (Healey, 1996.). Osim što su ovi akteri identifikovani kao učesnici u procesu planiranja, oni predstavljaju grupe koje mogu biti pogođene uticajima određenog projekta. Primetno je da broj ovako definisanih pogođenih aktera može biti jako veliki.

\section{Proces predvidjanja i analize uticaja}

Autori u oblasti SIA najčešće podržavaju stav da stručnjacima SIA treba prepustiti da odluče o tome kako će izgledati proces predviđanja i analize uticaja — ovo će zavisiti i od karaktera projekta, novčanih i vremenskih sredstava, itd. Mnogi od koraka u procesu SIA, koje predlažu organizacije kao što su IAIA ili ICGPSIA, su veoma opširni (suvišni u odnosu na specifičnost posmatrane akcije), ali su dati kao idealni slučaj, pod pretpostavkom da stručnjaci koji sprovode SIA imaju neograničene vremenske i novčane resurse. Stručnjaci bi na početku morali da odrede prirodu problema i zašto je toliko komplikovan da zahteva nekakvu akciju; obavezan korak u procesu SIA je provera da li je SIA potrebna, jer nepotrebna akcija može da iza-

13 Pri izradi SIA, u slučaju Stearling Medows, profesor Burdge je u potpunosti izostavio grupu latinoamerikanaca koji su bili pod uticajem projekta i istraživao samo uticaje koje će latinoameričko naselje imati na matično, dominantno belačko stanovništvo. Za detalje pogledati Burdge, R. J. and Western Washington students (2004.). 
zove dodatne probleme ${ }^{14}$ (Becker, 2001.). Proces predviđanja i analize uticaja može biti različit od slučaja do slučaja, ali zarad ilustracije prikazujemo kako ovaj proces izgleda prema dokumentu ICGPSIA (2003.): proces počinje temeljnim opisom intervencije urbanističkog i prostornog planiranja; zatim sledi određivanje zona uticaja i profila potencijalno pogođenih zajednica; određivanje ukupnog obima potencijalnih uticaja; projekcija mogućih reakcija na uticaje; predviđanje kumulativnih i sekundarnih uticaja; analiza uticaja, i na kraju dizajn scenarija mogućih razvoja situacije. Za analizu uticaja, odnosno njihovog intenziteta, potrebno je razviti set indikatora. Indikatori se formiraju u odnosu na pojedinačni projekat, ali sa stalnom podelom na kvantitativne i objektivne indikatore (direktno merljive), zatim kvalitativne i objektivne (nemerljive, ali zasnovane na proverljivim izvorima), kao i kvalitativne i subjektivne (zasnovane na percepciji) (World Bank, 2003.a). Indikatori definisani za analizu uticaja, kasnije se mogu koristiti u procesu monitoringa, o čemu će kasnije biti reči. Dalja istraživanja bi trebalo da pokažu kako izgledaju indikatori za predviđanje i vrednovanje/analizu potencijalnih uticaja u praksi, kroz studije slučaja SIA u oblasti urbanističkog i prostornog planiranja.

\section{Upravljanje uticajima i mere za ublažavanje i izbegavanje šteta}

Upravljanje uticajima se realizuje na dva načina: implementacijom predloga stručnjaka SIA u alternative planskih rešenja i razvojem plana za ublažavanje i izbegavanje posledica. Iako se u literaturi pojavljuje i slučaj kada stručnjaci SIA predlažu sopstvene alternative, treba imati u vidu da oni retko imaju snagu da predlože alternativna rešenja, ili da zaustave sprovođenje akcije. I relevantni autori navode da je ovo moguće samo u slučaju kada je SIA na vrhuncu moći (Burdge, 2003.). Dakle, u najboljem slučaju, rezultati SIA su osnova za formiranje alternativa plana, koje zatim i same prolaze kroz proces SIA (broj iteracija zavisi od raspoloživog vremena, finansija i veličine predložene akcije). U idealnim situacijama, planeri i stručnjaci SIA zajedno odlučuju o ovim alternativama, pre usvajanja plana. Svakako, alternativna rešenja bi trebalo da neutrališu većinu predviđenih negativnih uticaja.

Ukoliko ovakav postupak nije moguć ili alternativnim rešenjima nisu neutralisani negativni uticaji, razvija se plan za ublažavanje i izbegavanje uticaja, koji se realizuje nakon usvajanja plana. Istraživanja Svetske Banke (2003.b) i UNEP (2002.) navode primere dobre prakse razvoja plana za ublažavanje i izbegavanje uticaja iz različitih zemalja u razvoju, sprovođenih pod protektoratom međunarodnih organizacija. Sa druge strane, studije slučaja naselja Belingem u Vašingtonu (USA) i sela Doel kod Antverpena (Belgija) ukazuju da je teorija daleko ispred prakse po pitanju planova za ublažavanje i izbegavanje uticaja, s obzirom da su u ova dva slučaja, nakon završenog procesa SIA, rezultati u potpunosti ignorisani, iako su dokazani potencijalno intenzivni uticaji na stanovništvo (pogledati Gibbs and Haughton, 2008.; Marx, 2002.; Burdge and WWs, 2004.). Navedene studije slučaja pokazuju slab uticaj SIA

14 Ovo je jedan od aspekata SIA za koji je neophodno iskustvo i zbog kog je potrebno angažovanje lica koja su obučena da vrše SIA (Barrow, 2000.). 
kada ne postoji politička volja ili pritisak spoljnih tela da se izbegnu uticaji na socijalni razvoj.

Plan za ublažavanje/izbegavanje posledica ima dve faze: u prvoj, stručna lica minimizuju uticaje koji su posledica plana (minimizovanje ili izmena uticaja kroz implementaciju različitih mera, nezavisno od procesa planiranja, ili planirane intervencije); u drugoj fazi dolazi do kompenzacije za neželjene uticaje (kompenzacija za uticaje koji se ne mogu izbeći ili ublažiti). Obe faze često podrazumevaju dodatne politike, resurse ili opcije. Mere za ublažavanje/izbegavanje uticaja ne moraju biti obaveza aktera koji su pokretali i sprovodili intervenciju, niti je proces upravljanja uticajima autohtoni deo SIA, već može biti u preseku skupova nadležnosti procene uticaja i planiranja, ili u drugoj oblastiti ${ }^{15}$ (Becker, 2004.; ICGPSIA, 2003.). Potrebno je istražiti kolika su ovlašćenja stručnjaka SIA da upravljaju uticajima i predlažu mere; utiču na krajnju odluku o planskoj intervenciji; kako tokovi moći utiču na ovaj aspekt SIA; koje su prepreke da planeri i stručnjaci SIA zajedno donose odluke.

\section{Proces monitoringa}

U procesu SIA, koja se sprovodi u oblasti urbanističkog i prostornog planiranja, program za monitoring je obavezan za projekte koji imaju visok stepen nepostojanosti ili nesigurnosti. On prati predviđene devijacije koje su posledica predložene akcije i identifikuje one koje nisu predviđene u prethodnim koracima SIA. U idealnim uslovima, sprovođenje monitoringa se odvija kroz sve faze donošenja i sprovođenja planirane intervencije (ICGPSIA, 2003.). Ukoliko se uoče nepredviđeni uticaji i uticaji jačeg intenziteta od predviđenog, u ovoj fazi se predlažu dodatne mere koje će biti sprovedene kako bi se uticaj umanjio ili izbegao. U dokumentu ICGPSIA (2003.) se očekuje da će svi akteri (potencijalno pogođene strane i učesnici u procesu planiranja i procene uticaja) doprineti procesu monitoringa, tako što će reagovati na nepredviđene događaje. Stručnjaci SIA odgovaraju na sledeća pitanja pri definisanju strategije za monitoring: koji je minimum indikatora (kvalitativnih i kvantitativnih) potrebnih da bi se pratili socijalni ishodi projekta; da li će projekat imati koristi od participacije svih zainteresovanih u monitoringu; koji ce resursi biti potrebni kako bi aktivnosti monitoringa sprovele bez teškoća; u odnosu na prirodu intervencije, koja vrsta nadzora nad sprovođenjem plana će biti neophodna kako bi se pratili socijalni uticaji, itd. Proces monitoringa podrazumeva kombinaciju metoda, kao što je podsticanje participanata da prate akcije, intervjui sa ključnim akterima, razgovori sa fokus-grupama, socio-ekonomska istraživanja, Participativna procena siromaštva (Participatory poverty assessment — PPA), itd. (World Bank, 2003.a; Directive, 2001.) Sve ove procedure moraju se skrojiti posebno u odnosu na svaki

15 Mera za ublažavanje uticaja urbanističkih i prostornih planova može biti poreska olakšica, što ne spada u delokrug planera ili stručnjaka SIA, donošenje novog planskog dokumenta (delokrug planera), izrada plana za upravljanje socijalnim promenama (social management plan - poveren stručnjacima SIA), ili kombinacija ove dve mere (kroz saradnju planera i stručnjaka SIA). 
urbanistički i prostorni plan koji se posmatra, i iz ovog razloga bi dalja istraživanja u vezi sa monitoringom trebalo da pokriju studije slučajeva iz prakse.

\section{Postupak sprovođenja SIA i proces planiranja}

U literaturi nema puno informacija o odnosu procesa SIA i procesa planiranja. Jedan od retkih članaka na ovu temu je visokocitirani članak Rabel-a Burdge-a — The social impact assessment model and the planning process (2004.b). Burdge smatra da su proces planiranja i proces SIA racionalni i transparentni po karakteru, i da ih vodi ista filozofija. (Burdge, 2004.a) Ipak, treba uzeti u obzir da su oba procesa slobodna i prepuštena stručnjacima, i da je nemoguće napraviti model kombinovanja ova dva procesa primenljiv u svakoj situaciji — naročito uzevši u obzir brojne modele procesa planiranja kombinovane sa različitim planskim sistemima, i socijalnim, ekonomskim i političkim uslovima u kojima se sprovode (Rickson i sur., 1990.). U ovakvim okolnostima, preostaje da se istraži kako proceduralno i načelno funkcioniše saradnja donosilaca odluka, planera i stručnjaka SIA. U pitanju je vitalni deo čitavog procesa, jer se mogućnost stručnjaka SIA da utiču na smanjenje ili neutralisanje negativnih uticaja u velikoj meri sadrži upravo u ovoj saradnji.

\section{Zaključak}

Težište prikazanog istraživanja je stavljeno na definisanje SIA u urbanističkom i prostornom planiranju. Definisanjem SIA u ovoj oblasti otvara se mogućnost za operacionalizaciju njenih elemenata i formiranje okvira u kome će se ovaj postupak sprovoditi efikasno i efektivno. Definicija otvara i pitanja za dalja istraživanja, koja je potrebno sprovesti kako bi se i pojedinačni segmenti SIA definisali i odredila njihova uloga i okvir delovanja u urbanističkom i prostornom planiranju. SIA može da postane veoma važan mehanizam za zaštitu socijalnog razvoja u prostornom i urbanističkom planiranju. Bez obzira na nemogućnost da uvek utiče na ishod donešenih odluka, SIA ukazuje na potencijalne negativne strane razvojnih akcija i pomaže planerima da se približe postizanju osnovne svrhe urbanističkog i prostornog planiranja: da obezbedi ljudima uslove za život koji ti isti ljudi visoko vrednuju, i uspostavi sistem stabilnog, pravednog i održivog upravljanja razvojem. 


\section{Literatura}

1. Akpofure, E. A. and Ojile, M. (2002). Social impact assessment: an interactive and participatory approach, in: UNEP studies of EIA practice in developing countries - UNEP EIA Training resource manual, Topic 13: Social impact assessment. 211-222.

2. Anderson, J. (2008). Talk to the hand? Community councils and planning consultation. Planning theory, 7 (3): 284-300.

3. Baines, J. and Taylor, N. (2002). Institutionalising SIA in rapidly developing economies - the Malaysian case. 22nd Annual conference of the IAIA, Hague, Netherands, 15-21.06.

4. Barrow, C. J. (2000). Social impact assessment: an introduction. London: Arnold.

5. Becker, H. A. (2001). Social impact assessment. European journal of operational research, 128 (2): 311-321. doi: 10.1016/S0377-2217(00)00074-6

6. Becker, H. A. (2004). Social impact assessment. London: Routledge.

7. Burdge R. J. (2003). The practice of social impact assessment - background. Impact assessment and project apraisal, 21 (2): 84-88.

8. Burdge, R. J. (Ed.) (2004a). The concepts, process and methods of social impact assessment: Rabel J. Burdge and Colleagues. Middleton: Social ecology press.

9. Burdge, R. J. (2004b). Social impact assessment and the planning process, in: R. J. Burdge (Ed.). The concepts, process and methods of social impact assessment: Rabel J. Burdge and Colleagues. Middleton: Social ecology press.

10. Burdge, R. J. and Johnson, S. (2004). The comparative social impact assessment model, in: R. J. Burdge (Ed.). The concepts, process and methods of social impact assessment: Rabel J. Burdge and Colleagues. Middleton: Social ecology press.

11. Burdge, R. J. and Western Washington students (2004). Building low income housing in established neighborhoods: real versus perceived social impacts, in: R. J. Burdge (Ed.). The concepts, process and methods of social impact assessment: Rabel J. Burdge and Colleagues. Middleton: Social ecology press.

12. Burdge, R. J. (2009). Social impact assessment, (http://www.socialimpactassessment.net/).

13. Čaldarović, O. i Šarinić, J. (2010). Socijalna važnost prirode u urbanom kontekstu. Društvena istraživanja, 19 (4-5): 733-747.

14. Directive 2001/42/EC of the European Parliament and of the Council on the assessment of the effects of certain plans and programs on the environment. (http://eur-lex.europa.eu/LexUriServ/LexUriServ.do?uri=OJ:L:2001:197:0030:003 7:EN:PDF).

15. ESDP - European Spatial Development Perspectives (1999). Prepared by the Committee on Spatial Development. Potsdam: Published by the European Commission. (http://ec.europa.eu/regional_policy/sources/docoffic/official/reports/ pdf/sum_en.pdf).

16. European bank for reconstruction and development, EBRD (2008). Politika zaštite životne sredine $i$ socijalna politika. (http://www.ebrd.com/russian/ downloads/about/sustainability/espserb.pdf).

17. European bank for reconstruction and development, EBRD (2009a). Project summary document. (http://www.ebrd.com/projects/psd/psd2009/39750t.pdf). 
18. European bank for reconstruction and development, EBRD (2009b). Serbia corridor $X$ highway project E-75 and E-80. (http://www.ebrd.com/projects/psd/ psd2009/39750t.pdf).

19. Fainstein, S. S. (1997). Justice, politics, and the creation of urban space, in: A. Merrifield and E. Swyngedouw (Eds.). The urbanization of injustice. New York: New York University Press.

20. Fainstein, S. S. (2005). Planning theory and the city. Journal of Planning Education and Research, 25: 121-30.

21. Flyvbjerg, B. (1998). Rationality and power: democracy in practice. Chicago: The University of Chicago press.

22. Flyvbjerg, B.; Bruzelius N. and Rothengatter W. (2003). Megaprojects and Risk: An Anathomy of Ambition. Cambridge: Cambridge University Press.

23. Freudenburg, W. R. (1986). Social impact assessment. Annual Social Review, 12: 451-478.

24. Gibbs, D. and Haughton, G. (2008). Working Paper 1: Port of Antwerp. Hull and Humber City Region Observatory, Department of Geography, University of Hull, Hull. (http://www.hull.ac.uk/hhcro/pdf/Antwerp.pdf).

25. Healey, P. (1992). Planning through debate: a communicative turn in planning theory. Town planning review, 63 (2): 143-162.

26. Healey, P. (1996). The communicative turn in planning theory and its implications for spatial strategy formation, in: S. Feinstein and S. Campbell (Eds.). Readings in planning theory. Malden: Blackwell publishing.

27. Henry, R. (1990). Implementing social impact assessment in developing countries: a comparative approach to the structural problems. Environmental impact assessment review, 10 (1/2): 91-101.

28. Huxley, M. (2000). The limits to communicative planning. Journal of planning education and theory, 19 (4): 369-377. doi: 10.1177/0739456x0001900406

29. IAIA - International Association of Impact Assessment. (2003). Social impact assessment - international principles. Special publication series No. 2. (http:// www.iaia.org/publicdocuments/Pubs_Ref_Material/sp2.pdf).

30. Innes, J.E. (1996). Planning through consensus building: A new view of the comprehensive planning ideal. Journal ofthe American PlanningAssociation 62(4): 460-472.

31. Jokić, V. i Petovar, K. (2010). Procena uticaja na socijalni razvoj u projektima otvaranja i širenja površinskih kopova, u: N. Spasić i J. Petrić (Ur.). Prostorni, socijalni i ekološki aspekti održivog razvoja u velikim ugljenim basenima. Beograd: IAUS. Tematski zbornik (61).

32. Lakićević, D. M. (2001). Socijalni razvoj i planiranje. Beograd: FPN.

33. Marx, A. (2002). Uncertainty and social impacts: a case study of a Belgian village. Environmental impact assessment review, 22 (1): 79-96. doi: 10.1016/ S0195-9255(01)00092-0

34. Momtaz, S. (2005). Institutionalizing social impact assessment in Bangladesh resource management: limitations and opportunities. Environmental impact assessment review, 25 (1): 33-45.

35. Nedović-Budić, Z.; Tsenkova, S. and Marcuse, P. (2006). The urban mosaic of post-socialist Europe, in: S. Tsenkova and Z. Nedović-Budić (Eds.). The urban mosaic of post-socialist Europe: space, institutions and policy. Heilderberg: Physica-Verlag. 
36. Rickson, R. E.; Burdge, R. J.; Hundloe, T.; McDonald, G. T. (1990). Institutional constraints to adoption of social impact assessment as a decision-making and planning tool. Environmental impact assessment review, 10 (1/2): 233-243. doi: 10.1016/0195-9255(90)90022-R

37. Sager, T. (2005). Communicative planners as naive mandarins of the neo-liberal state. European journal of spatial development, December, 9pp.

38. Stanilov, K. (2007). Urban planning and the challenges of post-socialist transformation, in: K. Stanilov (Ed.). The post-socialist city: urban form and space transformations in central and eastern Europe after socialism. Dordrecht: Springer.

39. Taylor, N.; Goodrich, C.; Fitzgerald, G.; McClintock, W. (2006). Undertaking longitudinal research, in: H. A. Becker and F. Vanclay (Eds.). International handbook of social impact assessment. Cheltenham: Edward Edgar Publishing.

40. Taylor, C. N.; Bryan, C. N. and Goodrich, C. G. (2004). Social assessment: theory, proces and techniques ( $3^{\text {rd }}$ ed.). New Zeland: Social ecology press.

41. Tsenkova, S. and Nedović-Budić, Z. (2006). The post-socialist urban world, in: S. Tsenkova and Z. Nedović-Budić (Eds.). The urban mosaic of post'socialist Europe: space, institutions and policy. Heilderberg: Physica-Verlag.

42. UNEP (2002). UNEP studies of EIA practice in developing countries - UNEP EIA Training resource manual, Topic 13: Social impact assessment, 461-487. (http://www.unep.ch/etu/publications/EIA 2ed/EIA E top13 body.PDF).

43. Vanclay, F. (2002). Conceptualising social impacts. Environmental impact assessment review, 22 (3): 183-211. doi: 10.1016/S0195-9255(01)00105-6

44. Vanclay, F. (2006). Conceptual and methodological advances in social impact assessment, in: H. A. Becker, and F. Vanclay (Eds.). International handbook of social impact assessment. Cheltenham: Edward Edgar Publishing.

45. World Bank (2003a). A users guide to poverty and social impact analysis. (http://www.mfcr.cz/cps/rde/xbcr/mfcr/WB ImpactAssess PovertySocial UsersGuide_2003\%281\%29.pdf).

46. World Bank (2003b). Social analysis sourcebook: incorporating social dimensions into Bank-supported projects. Social development department. (http://siteresources.worldbank.org/EXTSOCIALDEV/Resources/3177394-1168615404141/So $\underline{\text { cial+Analysis+Sourcebook+FINAL+2003+Dec.pdf?resourceurlname=Social+Anal }}$ ysis+Sourcebook+FINAL+2003+Dec.pdf).

47. World Bank (2010). Social Impact Assessment. (http://go.worldbank.org/YAHA$\underline{\mathrm{RCJEQO}}$. 
Danijela Milojkić

Faculty of Architecture, Department of Urban Planning, University of Belgrade, Serbia

e-mail: st.milojkic@gmail.com

\title{
Social Impact Assessment in Urban and Regional Planning
}

\begin{abstract}
European institutions, international organizations and a number of theoretical works hold a view that the Social impact assessment - the SIA analysis - contributes to a stable, equitable and sustainable development management, preventing the unnecessary waste of money and other resources on neutralizing the negative effects of planned interventions. However, most often than not, the phrase 'planned intervention' does not denote an intervention in the field of urban and spatial planning - it indicates any action in any sector which was planned in advance and has a potential impact on life quality. The lack of specific differentiation of the SIA definition in relation to urban and regional planning represents a problem when establishing the framework in which the SIA is conducted in this area - there are difficulties in the operationalization of the problem, the defining of actors and the formulation of further issues which occur in the attempt to conduct the SIA. This paper presents the complexity of the existing definitions of the SIA, an attempt to unify their diverse elements through content and critical analysis and, after defining the SIA framework for spatial and urban planning, it offers further research guidelines which will allow professionals to manage this mechanism efficiently and effectively.
\end{abstract}

Key words: elements of the SIA, product of planning, development processes, decision making, consequences of the development. 